\title{
Humans created God in their image? An anthropomorphic projectionism in the Old Testament
}

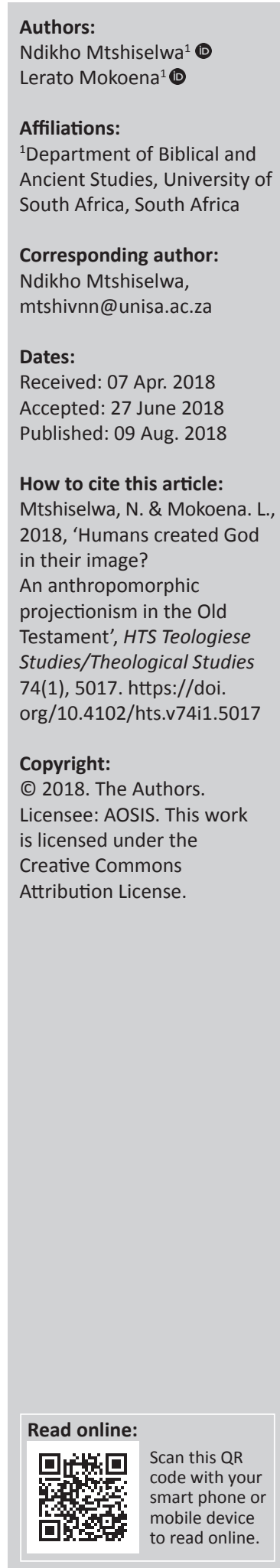

\begin{abstract}
The Old Testament projects not only a Deity that created the world and human beings but also one that is violent and male. The debate on the depiction of the God of Israel that is violent and male is far from being exhausted in Old Testament studies. Thus, the main question posed in this article is: If re-read as 'Humans created God in their image', would Genesis 1:27 account for the portrayal of a Deity that is male and violent? Feuerbach's idea of anthropomorphic projectionism and Guthrie's view of religion as anthropomorphism come to mind here. This article therefore examines, firstly, human conceptualisation of a divine being within the framework of the theory of anthropomorphic projectionism. Because many a theologian and philosopher would deny that God is a being at all, we further investigate whether the God of Israel was a theological and social construction during the history of ancient Israel. In the end, we conclude, based on the theory of anthropomorphic projectionism, that the idea that the God of Israel was a theological and social construct accounts for the depiction of a Deity that is male and violent in the Old Testament.
\end{abstract}

\section{Introduction}

In an interesting volume, Wrestling with the Violence of God: Soundings in the Old Testament, Wilgus and Carroll (2015) address a pertinent issue of the problematic image of God in the Old Testament. The authors examine the explicit portrayals of divine violence as well as human responses to the violence of God, violence in the world of the Old Testament and alternative understandings of supposedly violent texts. The present article seeks to contribute to the ongoing discussion about the depiction of YHWH as violent in the Old Testament. However, the interest of this essay lies at the intersection of philosophy, theology and biblical studies, as well as gender studies. Thus, we pose a cardinal question: based on the theory of anthropomorphic projectionism, how does the idea that YHWH was a theological and social construct account for the depiction of a Deity that is male and violent in the Old Testament?

The mystery surrounding the existence of a transcendental being that is omnipotent and omniscient has been debated throughout the annals of history. It is, however, the phenomenological core of the conceptualisation of this deity that is most intriguing. Some philosophers have faulted the claim that human beings created a transcendental being for themselves, arguing that a particular construct of divinity does not exist. The foundational argument is that humans, being conscious of their abilities and their limitations, and in a move to consolidate themselves with everything around them, have extended their human characteristics to the divinity. Everything that is around them and whatever cannot be accounted for through logical reasoning and empirical evidence must surely be just like them. If they have no cognitive access to certain things, human beings would rather imagine those things to be exactly like them. Is it therefore possible that humans imagined the character and person of the Deity of ancient Israel - YHWH? To address the main question posed by this article (i.e. if re-read as 'humans created God in their image', would Genesis 1:27 explain the portrayal of a Deity that is male and violent?), we follow this outline:

- human conceptualisation of a deity - remarks on anthropomorphic projectionism

- theological and social construction of YHWH

- an anthropomorphic projection of a violent male deity.

\section{Human conceptualisation of a deity - Remarks on anthropomorphic projectionism}

Studies of philosophy and religion reveal that gods have often been anthropomorphised. On a theoretical level, anthropomorphism alludes to an attempt, on the part of humans, to imbue the 
real and the imagined behaviour of non-human agents with humanlike characteristics, motivations, intentions or emotions (Epley, Waytz \& Cacioppo 2007:864). The anthropomorphic view describes a deity in and through human terms. Human conceptualisations are projected to a deity. Worthy of note is Guthrie's (1993:63) argument that anthropomorphism is inevitable to the human schemata of perception, specifically in religion, science and philosophy. This holds true because perception and cognition, which form part of the process of anthropomorphising, are unavoidable when humans attempt to make sense of who and what a deity is. One thus wonders whether anthropomorphism provides a convincing theory that could describe what a deity is. From a theoretical point of view, Westh (2009:1) notes that anthropomorphism 'is an argument with several separate lines of reasoning, and several different kinds of empirical evidence to support it'. Thus, it is necessary to consider some philosophical theories of anthropomorphism.

Hamori (2008:28) makes an interesting analogy between the various categories of anthropomorphism. In the first case of 'concrete anthropomorphism', although not physically present, the deity can be seen or heard. In Genesis 28:13, Jacob saw YHWH 'standing beside him'. In Amos 9:1, YHWH is 'standing at the altar'. Both of these texts project YHWH as a deity with human characteristics, such as the ability to stand. However, that the deity's appearance is revealed only through a vision is besides the point. What is important is that anthropomorphism ascribes human characteristics to a deity. Secondly, 'immanent anthropomorphism' presents $\mathrm{YHWH}$ as immediately present in a non-literal and nonembodied nature (Hamori 2008:28). In this category, the subject, for instance, Elijah, encounters the Deity in a theophany; YHWH came to Elijah in the form of a voice instead of appearing to him physically (1 Ki 19:11-12). Thirdly, 'transcendent anthropomorphism' is a category in which the Deity is not concretely embodied or explicitly envisioned and is not immanent (cf. Hamori 2008:28). The preceding category places the Deity in the 'heavens', where he is involved in a myriad of seemingly human activities. In this case, not only does the Deity speak and create (cf. Gn 1), but he also plants a garden (cf. Gn 2) and has a divine council (cf. Ps 82:1). Fourthly, 'figurative anthropomorphism (or metaphoric anthropomorphism)' ascribes to the deity certain symbolic imagery such as having a 'righteous hand', among other images (Hamori 2008:28; cf. Is 41:10). These theoretical categories of anthropomorphism that are teased out of biblical texts show clearly that the Deity is caricatured in human terms. In other words, human terms are projected onto a deity who is described as having a body, name, face, dwelling place and emotions.

Based on the categories of anthropomorphism, one could ask how, by ascribing human characteristics to a deity, human beings can know 'god', know what he wants, what he feels and how he is and whether they have any cognitive access to that god (cf. Barret 1998:609; Guthrie 2002:54). On the one hand, humans know 'god' or the divine being because in them exists a part of the divine. As shown by the priestly authors, the Deity in Genesis 1 breathed on humans. The deity is an object that humans are preoccupied with in anthropomorphism. As Feuerbach (1881:9) has argued, whatever object a human being is preoccupied with reveals something about himself or herself because a human being is nothing without an object. Consciousness of a deity is therefore, in essence, self-consciousness and knowledge of a deity is self-knowledge. On the other hand, in the process of conceptualising a divine being, humans reveal something about themselves - their abilities, limitations, wishes and desires, among other human elements. However, the ascription of the consciousness of a deity to the consciousness of self does not mean that humans are directly aware and conscious of themselves and their identity.

According to Findlay's (1977:672) interpretation of Hegel's phenomenology of the spirit, the encounter between the subject (humans) and the so-called absolute being (a deity) in religion is not a case of being aware of a 'spirit' (completely developed), because an absolute being as a construct is not aware of itself as the subject. An absolute being is thus not fully developed because the subject, as an unhappy consciousness, yearned (projected) for the absolute without first recognising the absolute as itself. Anthropomorphic projectionism as a theoretical framework therefore focuses on the images humans project to an 'absolute being' (god) in an attempt to know 'god', know what the god wants, what he feels and how he is. The attempt is therefore part of a perceptual strategy that is inevitable (Guthrie 1993:64). Thus, Gericke (2003:151) identifies polymorphic projection with particular reference to the all-too-human god of the Old Testament. On the issue of a deity that appears all too human, Gericke (2003) reasons:

Yahweh himself believes that the earth was created in six days (i.e. Gen 1:1-2; Ex 31:17) ... Yahweh himself believes that he lives in the sky just above the earth (i.e. Gen 11:5-7; Isa 14:12-14) ... Yahweh himself believes that the moon is the source of light and not the reflector of it (i.e. Gen 1:14-16; Isa 30:26) ... Yahweh himself believes that humans are made of clay and dust (i.e. Gen 2:3; Ps 103:14 etc.) ... Yahweh believes in the mythical creatures such as Leviathan, Rahab, Behemoth, sea monsters, flying dragons, demons in the field, malevolent spirits of the night etc, (i.e. Job 40-41; Isa 30:6; Lev 17:7; Isa 31:14; Ams 9:3 etc.). (p. 152)

Gericke's view implies that a deity has the misconceptions and primitive understanding of nature that are often found in humans. Furthermore, YHWH's ideas are informed by myths and legends like those of the human speechwriters. It seems that the YHWH of the Old Testament possessed the same cultural and traditional beliefs as his devotees, which never seemed to transcend the ideologies of the Old Testament itself. The knowledge that YHWH had of the world and humans was relative to the speechwriters of the ancient biblical texts. YHWH had no knowledge of the universe and how the Earth was created; he had no knowledge of astronomy (the moon is not the source of light); he had no knowledge of human physiology (humans are not made of clay); and he had no knowledge of the natural world before Homo sapiens and mythical creatures. What we have in the 
Old Testament is anthropomorphic projectionism. Gericke's argument is plausible because the YHWH of the Old Testament seems not to be in tune with reality, life systems and order. The YHWH of the Old Testament seems to be only in accordance with everything his speechwriters accord to YHWH. YHWH wants the Israelites to invade occupied land (Jos 1-12), which is a modern-day violation and denial of human rights; YHWH orders the killing of children (2 Ki 2:23:24; Gn 22:1-12; Nm 16:41-49). Gericke (2003:153) affirms that although it is embarrassing to conservative scholars, YHWH, as depicted in the ancient biblical texts, is indeed a construct created by humans for ideological, theological and social purposes. He exists only in literal texts for the purpose of those literal texts.

\section{Theological and social construction of YHWH}

A critical question to ask is: Did humans indeed create YHWH in their likeness? Deuteronomy 4:16 reads: 'so that you do not act corruptly by making an idol for yourselves, in the form of any figure - the likeness of male or female'. The text expresses a prohibition against the making of humanlike material forms (cf. Ex 20:2-5). It is thus ironic, specifically in light of anthropomorphic projectionism, that human beings constructed $\mathrm{YHWH}$ in their likeness, as will be argued shortly. That the YHWH of the Old Testament is anthropomorphised is a result of what Barret and Keil (1996:219) call 'ontological gap'. Human knowledge of how things are - ontological knowledge - is based on how they make sense of the world and how they in turn integrate themselves into such a world. Entities that do not conform to existing ontological knowledge and those that humans do not have access to present a challenge. In turn, humans construct entities that are complex to construe according to their being and identity because of the immediate knowledge of self. In order to make sense of the world, humans construct their contextual realities based on limited individual experiences. The construction of reality occurs when humans degrade human life, norms and values, rather elevating those that are outside of lived experience. Based on Nietzsche's motif of hic et nun, the danger of the latter occurrence is that it deprives an individual of the process of affirming life on its own terms. However, it is important to take a closer look at the biblical text.

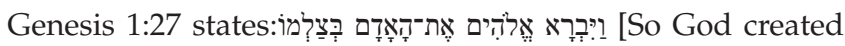
humankind in his image]. The key root words in the preceding

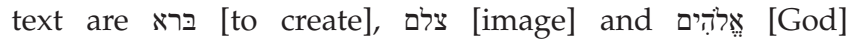
(Westermann 1987:146). Noteworthy, Wardlaw (2014:506-509) translates the verb בּרא as 'to separate', but the original meaning of the verb ברא , from the Arabic bry, may mean 'to cut off, chisel and shape' images, which were rife in temples. Furthermore, the root צלם in Genesis 1 denotes that humans are in the image of God. Interestingly, a similar root is employed in other biblical texts to denote lifeless idols made by humans (cf. Nm 33:52; 2 Ki 11:18; 2 Chr 23:17; Ezk 7:20, 16:17; Am 5:26). The verb צלם in essence designates the production of something new. However, if the Genesis creation story is compared to the Babylonian epic of Enuma Elish, the verb צלם would also mean 'to separate' (Wardlaw 2014:505). It is important to note that Genesis 1:27 forms part of the priestly theology; therefore, not only do בלם and denote the building of the temple by humans, these root words may also presuppose that YHWH 'constructed', 'carved' or 'shaped' humans in his own image. In an attempt to arrogate the supernatural ability to create human beings in one's image and likeness to the Deity, the priestly writers probably sought to separate ordinary human activities and characteristics from those of the Deity. However, the argument that supernatural abilities were allocated to the Deity fits within the framework of anthropomorphic projectionism because such abilities were allocated by humans.

Simango (2006:26) argues that in older texts that could be ascribed to $P$, the verb qnh is employed instead of bry. In texts such as Genesis 14:19, the verbs 'to beget' and 'to create' have their roots in West Semitic languages that could be used to denote either a divine activity or a human action. In Ugaritic texts, the verb is attested in epithets of the Canaanite god Ilu and his wife Athiratu. In Genesis 14, El is called the 'creator of heaven and earth'. However, to avoid ambiguity, it is possible that $\mathrm{P}$ employed the verb bry for his own theologically motivated reasons, namely, to ascribe divinity to the text. This then means that the postexilic Priestly writer who was responsible for the final redaction of Genesis 1 was probably acquainted with the Babylonian creation myths, which claim that the Babylonian god Marduk first defeated the sea monster Tiamat. The claim subsequently gave rise to the idea that in Israel, the work of the creator was preceded by a combat between God and sea monsters. However, the Priestly authors of Genesis 1 distanced themselves from that idea.

In Genesis 1, the creative work of the Deity did not commence with the combat with the sea monster. It is thus likely that the Priestly authors of this text sought to break away from the ancient Near Eastern idea of divine beings (i.e. kings were made in the image of a god). That the Priestly scribes were in a possible position of influencing the views of their addressees is not an impossible thought, especially that authors and redactors held their ideologies at the time of their scribal activity. A cardinal question to pose is: if the creation narrative was a construct of the Priestly authors, what then can we make of the narrative about the creator? Asked differently: is it likely that the image of the creator in Genesis and the rest of the Old Testament was created by the scribes, especially in the light of the view that the creation story was written by human beings? Inevitably, the authors and final redactors constructed a particular theology that undergirded their narrative and biblical myths in order to propound a certain ideology.

It is thus reasonable to reconsider Gericke's aforementioned view of polymorphic projection. Gericke argues that the Deity in ancient Israel was a construct that could have been influenced and appropriated to fit various situations. It therefore comes as no surprise that the role of a father, warrior, warlord, executioner and gender-biased god could 
be assigned to a deity because the portrait of a god was constructed to make his image relevant to a particular context. The point that a deity (particularly in the case of $\mathrm{YHWH}$ ) instructed the Israelites to invade nations that already occupied the land through a massacre confirms the preceding view. More importantly, the idea that the Priestly authors claimed that the land belonged to YHWH supports the view that the image of a deity who killed the people of other nations so that his own subjects could occupy their land was in the mind of the addressees of the $\mathrm{P}$ authors. Furthermore, the propagated view of a violent deity may have resulted in the idea and practice of heavy taxation and of offering of daughters to strangers.

\section{An anthropomorphic projection of a violent male deity}

Meyer (2011:1) asserts that 'the Bible is a collection of violent books' and that 'the Bible is full of spilled blood'. However, as Scheffler (2014:583, cf. note 19) has correctly observed, Meyer's argument is no less than an exaggeration because the Old Testament also contains expressions of YHWH's love. It is significant nonetheless that Meyer, in line with several biblical scholars, raises a critical question on the portrayed violent image of YHWH in the Old Testament as well as its implication for the interpretation of ancient texts both in their ancient and in modern contexts (cf. Masenya [ngwan'a Mphahlele] 2012:205-216).

The debate on the images of violence in the ancient biblical text sheds light on the image of a violent male deity. Old Testament commentators provide various scenarios for construing the images of a violent deity. Firstly, although the occurrence of violent images of $\mathrm{YHWH}$ are indisputable, it seems safer simply not to mention or critically engage with them (Baumann 2006:73; cf. Meyer 2011:4). However, ignoring the violent images of $\mathrm{YHWH}$ fails to address the problem of divine images of violence in the Old Testament (Masenya [ngwan'a Mphahlele] 2012:212), as we shall show subsequently. The second scenario is that it is reasonable to view the violent divine images as far from belonging to the so-called Zentrum [core] comprehension of YHWH (Baumann 2006:74). Consequently, far from being a violent deity, YHWH can only be a loving one (Meyer 2011:4). The perception of YHWH as only loving is not convincing because the Old Testament, particularly from a literary point of view, presents a deity, YHWH, who is also violent. The third scenario comes close to addressing the problem of the portrayal of a violent deity. As Baumann (2006:75-76) has noted, the divine images of violence reflect the world in which the text of the Old Testament originated. No doubt, 'it was a world in which violence was very much part of everyday life' (Meyer 2011:4). For instance, the idea of meting out capital punishment to people who engaged in idolatry (cf. Dt 13:12-17) may have stemmed from a historical context:

[T]he Assyrian loyalty oath of Essarhaddon ... actually constitutes an opposition to loyalty to an earthly being (king), thereby being subversive and initiating the idea of human dignity and 'rights'. (Scheffler 2014:586, note 29; cf. Otto 1999:86-90).
However, Achenbach (2012:21-26) locates the historical context of Deuteronomy 13 in the postexilic context, where the idea of warfare and the need to encourage Jews in an imperial context were rife (cf. Scheffler 2014:591). Achenbach's and Otto's location of Deuteronomy 13 may differ, but this is beside the point. The point here is that the portrayal of divine images of violence probably emanated from a historical context where various forms of violence often occurred, as will be shown shortly. The fact that some biblical scholars have called for the rewriting and retelling of the biblical narrative that would subvert the dominant vision of violence confirms the view that the Old Testament contains the image of a violent deity (Meyer 2011:2; Schwartz 1997:175-176). One may therefore ask: How did YHWH demonstrate violence in the Old Testament?

We shall consider a few selected Old Testament texts that imply that YHWH acted violently in the history of ancient Israel. Deuteronomy 32:39 reads:

See now that I, even I, am he; there is no god besides me. I kill and I make alive; I wound and I heal; and no one can deliver from my hand.

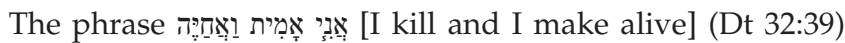
presupposes that $\mathrm{YHWH}$ is partly responsible for violence in ancient Israel because he is said to kill human beings. However, the same text also confirms that $\mathrm{YHWH}$ gives life. Thus, the point here is that YHWH could be held responsible for some killings in both the ancient biblical text and the history of Israel. Furthermore, the Pentateuchal text of Exodus 12:29 confirms that:

[a]t midnight the LORD struck down all the firstborn in the land of Egypt, from the firstborn of Pharaoh who sat on his throne to the firstborn of the prisoner who was in the dungeon, and all the firstborn of the livestock.

In that case, the angel of death received permission from YHWH to kill the firstborn sons of the Egyptians. Although the motive behind the killing of the Egyptian children is often applauded because it was meant to deliver the Israelites from oppression, it is clear that $\mathrm{YHWH}$ is implicated in the killing of human beings. Exodus 14:28 also suggests that YHWH killed non-Israelites - the Egyptian army. Furthermore, 2 Kings 19:35 shows that non-Israelite (Assyrian) soldiers who were at war with the so-called chosen nation (Israel) were killed by the angel of YHWH while they slept. All these cases confirm that YHWH often killed human beings, a point that the Israelites and the Israelite scribes did not convincingly problematise. In all the instances cited above, only men were killed by YHWH. One would then ask, what happened to women and children?

In Genesis 19:26, we read: 'But Lot's wife, behind him, looked back, and she became a pillar of salt'. In this instance YHWH is responsible for the annihilation of a woman. Lot's wife transformed into a pillar of salt because she did not obey the instruction of YHWH. The reason given for killing Lot's wife is not convincing, just as Ezekiel 24:15-18, which reveals that YHWH killed Ezekiel's wife, also offers no conclusive reason 
for the killing. Even though the motive may be somewhat unclear, it is indisputable that YHWH killed women. The Old Testament therefore depicts $\mathrm{YHWH}$ as a violent male deity. The killings of nations that are unwarranted and paint a very violent picture are noticeable as well (2 Ki 10; 11; Gn 19).

Although Masenya (ngwan'a Mphahlele) (2012:205-216) does not probe the texts of Genesis 19:26 and Ezekiel 24:1518 , she addresses the issue of gender-based violence that is discernible in Judges 19. Not only does Judges 19 highlight the invisibility of the female characters, it also reports a case of gang rape. Following Bach (1998:8), Masenya (ngwan'a Mphahlele) (2012:207) views the female characters in Judges 19 as victims of the narrator's narration. In addition, she notes that the 'male narrator chose to deprive her (The raped woman) of a voice even in the context of what can be designated an event akin to serial murder' (Masenya [ngwan'a Mphahlele] 2012:214). One wonders whether it suffices to hold only the narrator accountable for the violence against women and overlook the role of the Israelite men. Whilst Masenya (ngwan'a Mphahlele)'s view seems valid, a point worthy of note is that the Judges 19 story reflects an Israelite culture in which gender-based violence, the silencing of women and patriarchy were common. It is therefore unsurprising that the narrator of Judges 19 presents a story that scholars such as Trible (1984:65) prefer to forget, for Judges 19 'speaks of the horrors of male power, brutality and triumphalism; of female helplessness, abuse and annihilation' (Trible 1984:65). It is possible that some acts of violence in ancient biblical societies were influenced by the ancient text (and the narrators), but it is equally likely that the violence of YHWH that is documented in the Old Testament reflects the violence of humans. The world of the primary religions and especially of the Old Testament was far from being free of hatred and violence (Assmann 2010:16). Worthy of note, Judges 19, a text that treats a female case, which is culture specific, also exonerates YHWH as the culprit for the murder.

The point that the Old Testament projects a depiction of a violent male $\mathrm{YHWH}$ is conclusive. However, we also acknowledge that the ancient biblical text projects a loving YHWH. The view that the Old Testament emerged from a sociohistorical and cultural world that was also violent partly explains the depiction of a violent male YHWH. The theory of anthropomorphic projectionism provides a plausible explanation for the depiction of a violent male $\mathrm{YHWH}$ in the Old Testament. The narrators of biblical stories were probably compelled to present the portrayal of a deity that was a warrior in battle. In addition, YHWH's ill treatment of women in the Old Testament is not far from the ill treatment of women by the male characters in the world of the ancient texts. However, $\mathrm{YHWH}$ was also compassionate to many women in the OT and supported their cause (e.g. Hagar). The OT biblical accounts show YHWH to be violent only to the extent that persistent disobedience, rebellion and unrepentant sin persisted. His violence erupts only as a last resort. However, for these, the biblical projection of Israel's YHWH would always be loving, caring, merciful, compassionate and protective of the righteous.

\section{Conclusion}

Foregrounded on the theory of anthropomorphic projectionism, this article claims that the God of Israel was a theological and social construct by humans. This argument partly explains the depiction of $\mathrm{YHWH}$ as male and violent in the Old Testament. It may therefore be held that 'humans created God in their image'. Feuerbach's idea of anthropomorphic projectionism and Guthrie's view of religion as anthropomorphism support the claim that, although loving, the Deity of ancient Israel, YHWH, was depicted in a manner fitting to the world of the Old Testament.

\section{Acknowledgements Competing interests}

The authors declare that they have no financial or personal relationships which may have inappropriately influenced them in writing this article.

\section{Authors' contribution}

Both authors equally contributed to the research and writing of this article.

\section{References}

Achenbach, R., 2012, 'Divine warfare and YHWH's wars: Religious ideologies of war in the Ancient Near East and in the Old Testament', in G. Galil, A. Gilboa, A.M. Maeir \& D. Kahn (eds.), The Ancient Near East in the 12th-10th Centuries B.C.E: Culture and history. Proceedings of the International Conference, held at the University of Haifa, 2-5 May, 2010, Alter Orient Und Altes Testament 392, pp. 1-26, UgaritHaifa, 2-5 May,
Verlag, Münster.

Assmann, J., 2010, The price of monotheism, Stanford University Press, Stanford, CA.

Bach, A., 1998, 'Rereading the body politic: Women and violence in Judges 21', Biblical Interpretation 6(1), 1-19. https://doi.org/10.1163/156851598X00200

Barrett, J, L., 1998, 'Cognitive constraints on Hindu concepts of the divine', Journal for the Scientific Study of Religion 37(4), 608-619.

Barret, J.L. \& Keil, C.F., 1996, 'Conceptualizing a non-natural entity: Anthropomorphism in God concepts', Cognitive Psychology 31, 219-247. https://doi.org/10.1006/ cogp.1996.0017

Baumann, G., 2006, Gottesbilder der Gewalt im Alten Testament verstehen [Understanding divine images of violence in the Old Testament], WBG, Darmstadt.

Epley, N., Waytz, A. \& Cacioppo, J.T., 2007, 'On seeing human: A three-factor theory of anthropomorphism', Psychological Review 4(114), 864-886. https://doi.org/ 10.1037/0033-295X.114.4.864

Epley, N., Waytz, A. \& Cacioppo, J.T., 2010, 'Social cognition unbound: Insights into anthropomorphism and dehumanization', Current Directions in Psychological Science 19(1), 58-62. https://doi.org/10.1177/0963721409359302

Feuerbach, L., 1881, Essence of Christianity, transl. M. Evans, Trubner \& Co., Ludgate Hill, London.

Findlay, J.N., 1977, Hegel phenomenology of the spirit: Analysis of the text, Clarendon Press, Oxford.

Gericke, J., 2003, 'Does YAHWEH exist? A philosophical-critical reconstruction of the case against realism in Old Testament theology', PhD thesis, Dept. of Old Testament, University of Pretoria, Pretoria.

Guthrie, S., 1993, Faces in the clouds: A new theory of religion, Oxford University Press, New York.

Guthrie, S., 2002, 'Animal animism: Evolutionary roots of religious cognition', in I. Pyysiäinen \& V. Anttonen (eds.), Current approaches in the cognitive science of religion, pp. 38-67, Continuum, London; New York.

Hamori, J.E., 2008, 'When Gods were men: The embodied God in biblical and near eastern literature', Beihefte zur Zeitschrift für die alttestamentliche Wissenschaft (384), 36-185

Masenya (ngwan'a Mphahlele), M., 2012, 'Without a voice, with a violated body: Rereading Judges 19 to challenge gender violence in sacred texts', Missionalia 40(3), 205-216.

Meyer, E.E., 2011, 'The role of the Old Testament in a violent world', Verbum et Ecclesia 32(2), 1-8. https://doi.org/10.4102/ve.v32i2.502

Otto, E., 1999, Krieg und Frieden in der hebräischen Bibel und im Alten Orient: Aspekte für eine Friedensordnung in der moderne, T\&F 18, W. Kohlhammer, Stuttgart. 
Scheffler, E., 2014, 'Reflecting on (non-)violence in the book of Deuteronomy in (Old Testament) canonical context', Old Testament Essays 27(2), 579-596.

Schwartz, R.M., 1997, The curse of Cain: The violent legacy of monotheism, University of Chicago Press, Chicago, IL.

Simango, D., 2006, 'The image of God (Gen 1:26-27) in the Pentateuch: A biblical theological approach', Hons. B.A. thesis, Dept. of Old Testament, North West University, South Africa.

Trible, P., 1984, Texts of terror: Literary-feminist readings of biblical narratives, Fortress Press, Philadelphia, PA.
Wardlaw, T., 2014, 'The meaning of ברא in Genesis 1:1-2:3', Vetus Testamentum 64 502-513. https://doi.org/10.1163/15685330-12341166

Westermann, C., 1987. Genesis 1-11: A commentary, Augsburg, Minneapolis, MN.

Westh, P., 2009, 'Anthropomorphism in God concepts: The role of the narrative', in W.A. Geertz (ed.), Origins of religion, cognition and culture, pp. 1-21, Equinox Publishing Ltd, Sheffield.

Wilgus, J.B. \& Carroll, R.M.D., 2015, Wrestling with the violence of God: Soundings in the Old Testament, Eisenbrauns, Winona Lake, IN. 